\title{
DISCOURSES ON VIOLENCE AND PUNISHMENT: PROBING THE EXTREMES
}

\section{Krešimir Petković}

Lexington Books, Lanham, 2017.

DOI: 10.20901/an.15.11

Discourses on Violence and Punishment: Probing the Extremes opsežna je, dobra i važna knjiga koja je potpuno zasluženo dobila državnu nagradu za znanosti za 2017. godinu. Njome autor djelomice nastavlja i umnogome proširuje svoje istraživanje odnosa političke moći i politika kažnjavanja iz svoje prve, impresivne i uznemirujuće, knjige Država i zločin: politika i nasilje u Hrvatskoj 1990-2012. koja je objavljena 2013.

Knjiga Discourses on Violence and Punishment: Probing the Extremes, prema riječima autora, mogla se nazvati samo Discourses on Punishment, i to bi, prema mojem sudu, bio bolji naslov. Naime, središnji pojam i interpretacijski najzanimljiviji dio knjige upravo je kazna ili kažnjavanje. Taj pojam autor određuje posve neortodoksno, i to $s$ dva aspekta. Kazna je svaka "uporaba nasilja koja osobi ili skupini nanosi štetu ili ograničenja", a koja je "povezana s nekom idejom pravde" ili pokušajem "popravljanja, rehabilitacije ili reintegracije kažnjenika, te implicira... ovlast za kažnjavanje" (27). Tako široko shvaćanje kazne uključuje ne samo ono što se u okviru pravnog sustava neke države smatra zakonitim odgovorom na kazneno djelo, nego i ubojstva iz časti, osvete (osobne, obiteljske i političke), atentate pa čak i democide i genocide (29). Ono što omogućuje da kazna - iako samo u empirijskome, a ne i u normativnom smislu - bude tako definirana jesu diskursi o kažnjavanju koji nude razna, manje ili više opravdana i prihvaćena, opravdanja i priče o autorizaciji/ovlasti da kažnjava. Diskurs, drugi važan pojam, nije shvaćen u tehničkom smislu diskurzivne analize nego kao rasprava, ogled, traktat o temi. Najortodoksnije, iako ne i neosporivo, definiran je pojam nasilja kao fizički napad ili fizičko ograničavanje subjekta ili skupine, obično praćeno nekim opravdanjem (20).

Drugi neortodoksan aspekt pojma kazne čini široko shvaćanje onoga tko ili što određuje kakva će biti kaznena politika neke države ili nekoga političkog entiteta. To nisu samo zakonodavna, izvršna i administrativna tijela, pa ni mediji i javnost, nego ukupnost diskursa kažnjavanja koji su usko povezani s onime što autor naziva ontologijom, a što se najkraće može opisati kao odgovor na pitanje "kakav čovjek jest".

Podnaslov knjige Probing the Extremes upućuje na metodološki postupak koji autor naziva skeptičnim propitivanjem ekstrema. Autorova skeptičnost može se poistovjetiti sa stavom "you are not so smart" ili "niste baš tako pametni" (kao što mislite), jer je usmjerena, među ostalim, na to da dovede u pitanje mnoga uvriježena i globalno popularna stajališta o nasilju, poput onoga da se nasilje tijekom povijest smanjivalo, izložena u popularnoj knjizi harvardskoga bihevioralnog psihologa Stevena Pinkera The Better Angels of our Nature: Why Violence Has Declined.

Nakon uvodnog poglavlja u kojemu su objašnjeni pojmovi, slijedi osam po- 
glavlja napisanih u, kako kaže autor, različitim žanrovima: od političke teorije i komparativne društvene znanosti do tekstualne analize i kriminologije. Multidisciplinarnost i multiperspektivnost mogu čitatelju biti prilično napornima: teško je naći čitatelja koji će jednako uživati u svakom dijelu knjige, ali teško je naći i čitatelja koji neće uživati u makar jednom poglavlju.

U političko-teorijskom poglavlju "Smrtna kazna: politička teorija ekstremnog kažnjavanja" prikazani su stavovi o smrtnoj kazni decizionističkih političkih teorija (Schmitt, Cortés), anglosaksonskih teorija ugovora (Hobbes, Locke), utilitarističkih teorija (Beccaria, Bentham, Mill), kontinentalnih teoretičara ugovora (Rousseau, Kant, Hegel) i marksističkih teorija. U skladu s odabranim metodološkim postupkom, autor nalazi razlike u ontologijama prikazanih političkih teorija koje uvjetuju i stavove prema smrtnoj kazni. Predvidivo, decizionistima je čovjek ili zao ili dovoljno nepouzdan te je uspostava suverene vlasti odlukom kojom se stvara politički poredak preduvjet svake moralnosti i sigurnosti društvenog života. Kako bi takva vlast bila "shvaćena ozbiljno", odnosno kako bi uopće bila uspostavljena, ona mora imati pravo oduzeti život svojim podanicima. Ne treba posebno isticati da podanici nemaju nikakva prirodna, ljudska ili neka druga prava prije ili izvan uspostavljenoga decizionističkog poretka vladavine (54-58).

Nasuprot decizionistima, angloamerički kontraktualisti polaze od prirodnih prava čovjeka koja se društvenim ugovorom prenose na suverena (Hobbes) ili predstavničku vlast (Locke). Svi oni opravdavaju smrtnu kaznu u slučaju zlodjela koje podanike/građane označavaju kao kršitelje društvenog ugovora. I kod kontraktualista, osobito kod Hobbesa, predvidivo se pojavljuje problem kontradikcije između prirodnog prava na život i prava suverena da podaniku oduzme život (62-66). Čak i utilitaristi, koji poriču svaku težinu argumentu o retribuciji i uzimaju u obzir samo koristi i štete koje društvu donosi neka kaznena praksa, u određenim slučajevima opravdavaju smrtnu kaznu. To poglavito vrijedi u slučajevima pobune ili revolucije koje dovode u pitanje uspostavljenu vlast te kada nema drugog načina da se zaustavi širenje kaosa (68-72). I kontinentalni kontraktarijanci, koji također polaze od prirodnih prava, opravdaju smrtnu kaznu, jer se prirodna prava bez ostatka transformiraju u građanska prava i prenose na političku zajednicu koja ima pravo akte ubojstva, oružane pobune i drugih teških zlodjela kažnjavati smrću zato što tim djelima građani prestaju biti dijelom političke zajednice i pretvaraju se u njezine neprijatelje. Tako je makar kod Rousseaua. Kod Kanta je upravo prirodno pravo, ljudska sloboda, opravdanje za smrtnu kaznu budući da se samo tako zločinca tretira kao slobodno ljudsko biće i poštuje se njegovo dostojanstvo (80). Ako bi čitatelj pomislio kako, sukladno tome, ontološka stajališta različitih teoretičara nisu bitna budući da preporučuju jednake kazne, autor nudi neke argumente kojima se donekle može zadržati središnje mjesto ontologije u njegovu objašnjenju. Tako u tekstovima utilitarista nalazi iskaze o mogućnosti potpunog ukidanja smrtne kazne u budućnosti, kada će se možda dogoditi civilizacijski napredak, a kod nekih se teoretičara društvenog ugovora može govoriti o zaokruženosti teorijskog argumenta unutar kojega smrtna kazna nije nužnost, kao kod decizionista, nego samo mogućnost onda kada se teorija sudari s političkom praksom. To autor posebno ističe u vrlo zanimljivoj raspravi o Maximillianu Robespierru koji je 1791. održao vatren govor protiv smrtne kazne da bi potom postao njezin istaknuti provoditelj, koji je i sam završio na giljotini (79). 
Osim političkih teorija koje su s različitim argumentima prihvaćale, podupirale ili aktivno zagovarale smrtnu kaznu, autor prikazuje i abolicioniste (Camus, Hugo) koji poriču pravo sekularne države da se stavi na mjesto Boga i kažnjava smrću te dovode u pitanje i slobodnu volju ubojice koji je mogao biti pod "utjecajem okolnosti izvan njegove autonomne kontrole" (Koestler) (83). Naposljetku, i teološki se argument može okrenuti protiv smrtne kazne, kao u radikalnom Tolstojevu pacifizmu u kojemu smrtna kazna nije primjeren odgovor na nasilje počinitelja i ne vodi ni iskupljenju kažnjenika (kao kod Kanta) niti boljitku i većoj sigurnosti društva. Rješenje za nasilje nije nasilje, nego djelovanje u korist stvaranja pravednijeg društva u kojemu bi, u konačnici, nasilje moglo nestati (84). Marx i Engels, kao i drugi autori inspirirani marksizmom, ističu nepravednost smrtne kazne koju izvršava država, koja je i sama odgovorna za zločine uzrokovane eksploatatorskim ekonomskim sustavom koji štiti. Osim Marxove poznate ideološke kritike Hegela koji je zagovarao smrtnu kaznu, autor navodi i Marxovu empirijsku argumentaciju, zasnovanu na tada dostupnim statistikama zločina, prema kojoj se "još od Kaina svijet nije ni zastrašio ni poboljšao kažnjavanjem. Upravo suprotno" (87). No, kao što je također dobro poznato i što autor ističe, politički pokreti inspirirani marksizmom nisu se nimalo ustezali od masovnog korištenja nasilja u političke svrhe.

Na kraju poglavlja, uz primjere iz svijeta filma i fikcije, Petković, u skladu sa svojom metodom skeptičnog preispitivanja, ostavlja pitanje smrtne kazne otvorenim. S jedne strane, posve je jasan empirijski trend zabrane državnog ubijanja građana, dok je, s druge strane, on paradoksalno praćen legaliziranjem prava da isti ti građani sami sebi oduzmu život, pa čak i obvezom države da im $\mathrm{u}$ tome pomogne. No autor nije sretan zbog toga pa navodi da "ustavne promjene u smjeru liberalne demokracije i uspostave korespondirajuće kulture ljudskih prava vode $\mathrm{k}$ rastvaranju suverene moći kakvu svijet poznaje" (104). Tako se pregled klasičnih političkih teoretičara, koji češće opravdavaju nego što osuđuju smrtnu kaznu, čita kao makar blago upozorenje na ono što održava politički poredak, a filmski primjeri podsjećaju na nezamjenjivost iskupljujuće uloge smrtne kazne. Skepticizam pobjeđuje.

Drugo poglavlje o povijesti kažnjavanja i treće poglavlje o komparativnima kaznenim politikama možda su i najuvjerljivija potpora autorovim skepticizmu u pogledu na ono što naziva "vigovskom poviješću kažnjavanja". To je povijest napretka od okrutnoga i naizgled iracionalnoga ka humanijemu i racionalnijem kažnjavanju sve do jednoga trenutka u budućnosti kada kazne ne budu više potrebne (112-113). Nakon što na početku drugog poglavlja upozorava na to da kazne mučenja nisu nestale ni u 21. stoljeću - primjenjuju se u vojnima i paravojnim organizacijama, policijskim ispitivanjima, zločinačkim organizacijama te u donedavno vrlo eksponiranim akcijama Islamske države (117) - autor daje nasumičan pregled okrutnih i neobičnih kazni iz prošlosti. Primjeri koje navodi stvarno su neobični, pa tako saznajemo da je u Kini od 13. stoljeća postojala kazna ling chi ili horizontalno rezanje dijelova kažnjenika, a autor nas podsjeća i nabijanje ljudi na kolac koje nam je poznatije iz ovdašnje književnosti. Kako onda autor dovodi u pitanje humaniziranje kažnjavanja? Jedan je argument kako nema povijesnih zapisa o tome da su mučenja iz prošlosti ondašnjim ljudima bila neobična. Pozivajući se na Barringtona Moora, Petković ističe da su Rimljani iskreno uživali u okrutnim borbama u Kolo- 
seju (124-127), a razapinjanje na križ bilo je uobičajena kazna, kao i mnoge, danas izrazito odbojne, kaznene prakse zapisane u kaznenim kodeksima starih imperija (129). Dapače, autor upozorava na to da se ono što se čini očitim napretkom, a to je prijelaz s kažnjavanja tijela na "kažnjavanje duše" u zatvorskim samicama, nekim suvremenicima, kao Charlesu Dickensa, činilo "nemjerljivo gorim" (127).

Drugi dio poglavlja i skeptičnog argumenta sastoji se od prikaza i kritičkih komentara teorijskih tumačenja promjena u kaznenim praksama. Sociološka teorija Durkheima, marksistička tumačenja Ruschea i Kirchheimera, civilizacijski proces Eliasa i planetarno popularni Pinker identificiraju različite uzroke i utjecaje na kaznene prakse. Autor se ne opredjeljuje ni za jednu od njih te na primjerima koncentracijskih logora i smaknuća Gadafija (162-164) nastoji pokazati da svaka teorija može objasniti jedan aspekt kazne. Ostajući vjeran skeptičnom propitivanju ekstrema, na kraju poglavlja Petković zagovara objašnjenja konkretnih kaznenih praksi i srednjeg dometa umjesto epohalnih povijesnih tumačenja (159).

Opravdanost prednosti koju autor daje konkretnima, pa tako i lokalnim praksama kažnjavanja najbolje dolazi do izražaja u poglavlju o komparativnim politikama kažnjavanja. Iako kaznene prakse "putuju svijetom", lokalne ih okolnosti uvijek transformiraju. Uz to, to je poglavlje dobar primjer opravdanosti autorova opreza prema širokima komparativnim zahvatima koje nude statistike zatvorske populacije i poopćavanjima o blagosti kaznenih politika liberalnih demokracija. Primjeri na kojima autor razvija svoje teze potječu $s$ "globalne periferije", s Bliskoga i Dalekog istoka (Iran, Izrael, Singapur, Kambodža, Kina), i "europske poluperiferije" (Irska, Španjolska). Irski primjer možda najbolje sažima sve autorove teze i ograde, ali su i drugi primjeri sjajno izabrani i vrlo poučni. U Irskoj je, naime, pedesetih godina zatvorska populacija bila manja od četiri stotine da bi 2017. porasla na četiri tisuće zatvorenika. U skladu sa svojom širokom definicijom kazne, autor u kaznene institucije ubraja i sve "popravne domove", poput "domova" za nevjenčane majke kroz koje je prošlo više od trideset tisuća mladih djevojaka ručno perući rublje kao način iskupljenja za grijehe (211). Kada se broju zatvorenih "neudanih majki" doda broj zatvorenih u "popravnim" školama za mlade i institucijama za prisilno psihijatrijsko liječenje te u klasičnim zatvorima, zatvorska populaciji činila je 1951. oko jedan posto ukupnog stanovništva. Taj bi broj bio mnogo veći da se tradicionalno iz Irske nisu, zajedno s drugima, iseljavali i mnogi potencijalni kažnjenici. Kada se tome pribroji i tada općeprihvaćeno i masovno prakticirano nasilje u obiteljima, broj onih koji su u Irskoj trpjeli nasilje sigurno je bio mnogostruko veći od današnjih statistika kaznenih dijela i zatvorske populacije. Stoga Petković opravdano govori o ekstremima.

Ekstremi kažnjavanja u četvrtom su poglavlju povezani s ekstremima političke moći. Iako prikazuje i druga shvaćanja političke moći, kao svoj okvir Petković uzima Foucaultovu taksonomiju suverene, disciplinarne, biološke $i$ pastoralne moći. Ti se oblici moći mogu promatrati sukcesivno, u linearnome povijesnom slijedu, ali autor smatra da bi to bilo pogrešno. Autorov stav najbolje ilustrira "povratak" suverene moći u vrijeme stvaranja države i rata za neovisnost devedesetih godina u Hrvatskoj. Ukratko, autor opisuje modus operandi suverene moći u Hrvatskoj devedesetih godina kroz jaku izvršnu vlast koja djeluje izvan i mimo zakona, uz radikalno slabljenje pravosudnog sustava. Njezini su pojavni oblici velikodušno korištenje 
pomilovanja kažnjenika i pražnjenje zatvora, politička premlaćivanja i ubojstva koja su ostajala neriješenima i neprocesuiranima, mučenja izabranih neprijatelja i spektakl političkog nasilja općenito, a što se ne može pripisati ratnim operacijama (282). No ni uspostavljanje disciplinarne moći od 2003. nije donijelo očekivan predah od kažnjavanja. Uz moralnu paniku zbog nasilja, koje je uglavnom povezanog $s$ akterima naviklima na način funkcioniranja suverene moći, nova se disciplinarna moć kroz beskrajne birokratske i administrativne procedure i pravila širi fukoovski "kapilarno" i biva nadopunjena pastoralnom moći dušebrižništva (256-257). Petković vidi pastoralnu moć, koja je izvorno povezana $s$ religijskim vlastima, i u suvremenom načinu funkcioniranja tržišne privrede koja zahtijeva neprestano mjerenje učinaka, kvalitete, postignutih benchmarka, evaluacije, samoevaluacije. Najveći je grijeh neuspjeh, a najveća kazna suočavanje s "darvinističkim posljedicama" neuspjeha (258). No autor je uvijek na oprezu kako njegov skepticizam ne bi prešao u nihilizam i cinizam, pa nas na kraju poglavlja podsjeća na to da svaki oblik moći postavlja i pozornicu za "ljepotu otpora".

Svaki oblik moći povezan je sa "slikom čovjeka" i pitanjem kakav čovjek jest. U odgovorima na to pitanje razvijaju se diskursi koji utječu na kaznene politike. Peto i šesto poglavlje ilustracije su tih diskursa i u njima sadržanih shvaćanja nasilja i kazne. U petom poglavlju, koje je podnaslovljeno "Kako kažnjavaju velike religije?", autor analizira svete knjige islama, kršćanstva i budizma te uspoređuje njihove "slike čovjeka" i kazne koje su im primjerene. Otkriva se sličnost Starog zavjeta i Kurana u dominantno retributivnom shvaćanju kazne, te Novog zavjeta i budističkih spisa u naglašavanju oprosta i mogućnosti rehabilitacije grešnika. "Slike čovjeka" u literaturi i filmu predmet su šestog poglavlja u kojemu se na političku os lijevo-desno svrstavaju dijela Defoa, Solženjicina, Dostojevskog, Gorkog, Huxleya, Bulgakova, Saint-Exupéryja, Houellebecqa i drugih autora. Široko je zahvaćen i spektar igranih i dokumentarnih filmova pa će filmofili zasigurno s posebnim zanimanjem "uroniti" u taj dio knjige.

Politički naboj i perspektiva prikazanih umjetničkih i dokumentarnih dijela dobra su priprema čitatelja za poglavlje o kriminologiji u kojemu se sve vrti oko politike. Uska povezanost politike i kriminologije zapravo je posve očita. Država, to jest politika, mora najprije odrediti što je u pravnom smislu zločin, odnosno kazneno djelo, kako bi kriminologija dobila predmet proučavanja (445). Iako su kriminologija i politika usko povezane, ta veza nije jednoznačna. Kriminologija je izložena kritičkom udaru sa svih strana političkog spektra. $\mathrm{Za}$ desnicu, ona perpetuira srceparajući liberalizam (Johnsonova Velikog društva) koji je, prema riječima Newta Gingricha, "tridesetogodišnji eksperiment u uništavanju Amerike. Trideset smo godina oslobađali zatvorenike, tolerirali dilere, trpjeli nasilje..." (442). Za ljevicu, kriminologija "ignorira i ne prepoznaje strukturno nasilje, zlostavljanje i materijalnu zakinutost" (443). Treća je opcija da kriminologija govori ono što nitko ne želi čuti, a Petković navodi primjer donedavno proskribiranih biodruštvenih kriminoloških istraživanja (443). No kriminologija, zatvori i statistika kao njezina dva temelja, još su, u fukoovskom smislu, intimnije povezani s politikom, odnosno s politikom i ontologijom Moderne (448). To pak otvara problem epistemoloških ograničenja kriminoloških teorija i njihove korisnosti za penološku praksu. Naime, različite kriminološke teorije na različite su načine slijepe za svoja ograničenja, a upravo je adekvatan uvid u ono što je teorijski 
moguće nužan kako bi se formulirale dobre kaznene politike i prakse. Ako se pođe od pretpostavke da je zločine moguće potpuno iskorijeniti, ili od suprotne pretpostavke da će samo masovna primjena državnog nasilja obuzdati zle ljude, ili od neke treće, jednako obuhvatne teorije, ne može se doći do dobre politike. U skladu sa svojim skeptičnim stavom, Petković stoga zagovara korištenje različitih teorija kao "kombinacije orijentacijskih točaka" u praktičnim pristupima kažnjavanju (452).

Kao što se može nazrijeti, autorov skepticizam, brojne ograde i rezerve, opsežna dodatna objašnjenja vlastitih stavova i namjera čine knjigu teško prohodnom. Kada se tome dodaju brojne usputne zanimljivosti, anegdote, filmske, književne i općenito kulturne referencije koje nisu sve uklopljene u tekst tako da ne odvlače pozornost od tijeka argumentiranja, čitatelji bi mogli dobiti dojam da su izvrgnuti nekoj vrsti testa izdržljivosti. Na neki način to priznaje i autor navodeći da je "dramaturgija (njegove) ekspozicije epistemološka strategija otkrivanja raznih slijepih ulica" (462). Primjereno tome, tema je posljednjeg poglavlja teodiceja. Iako su i na početku posljednjeg poglavlja čitatelji izloženi, ni manje ni više, nego opisu četrdeset groznih zločina sa svih krajeva svijeta i iscrpnima teorijskim raspravama o podrijetlu i postojanju zla kao takvoga, sam je svršetak knjige gotovo poetski i dirljiv. $\mathrm{U}$ intimističkome i ispovjednom tonu autor analizira dvije biblijske priče, Kulu babilonsku i Priču o Jobu, pa knjiga završava u gotovo religioznom tonu. Zlo, nasilje i kazna ne mogu se bezostatno rastvoriti ni u jednome objašnjenju pa je vrlo neizvjesno hoće li ikad nestati s lica zemlje. Unatoč tome, ljudski rod ima dovoljno teorijskih i praktičnih resursa da se obrani moralna obveza činjenja dobra i bez postojanja božjih zapovijedi. Dapače, autor se nada da i njegova knjiga može u tome pomoći (536).

Kako je rečeno na početku, ovo je velika, dobra i važna knjiga. Ona sadržava brojne vrijedne uvide o kazni i njezinoj neraskidivoj vezi s politikom i široko shvaćenim diskursima o prirodi čovjeka. Čitatelji će često biti pozitivno iznenađeni time kako se politički trendovi mogu vrlo jasno osvijetliti, razumjeti pa i predvidjeti iz proučavanja kaznenih politika. U tom smislu, knjiga se može preporučiti politolozima i sociolozima, pravnicima i teolozima, kriminolozima i penolozima, kao i svima zainteresiranim čitateljima. Autor sam kaže da je ovo barokna knjiga, a odnos prema njezinim brojnim "ornamentalnim dodacima" ovisi i o estetskim sklonostima čitatelja. Zacijelo će se naći čitatelji koji će cijeniti podatak da je dio filma Sofijin izbor sniman u Zagrebu, da je Sinatrina pjesma My Way izvorno zapravo francuska šansona Comme d'habitude, da je Pol Pot bio na radnoj akciji u SR Hrvatskoj i slično. No najiskrenije preporučujem autoru, koji nesumnjivo posjeduje veliku kreativnu energiju i erudiciju, da sljedeću knjigu pokuša napisati u akademskoj inačici arhitektonskog modernizma ili, bolje, ogoljenog brutalizma.

Ana Matan 